\title{
Numerical Taxonomy of Hafnia alvei
}

\author{
SIGURDUR GREIPSSON AND FERGUS G. PRIEST* \\ Department of Brewing and Biological Sciences, Heriot-Watt University, Edinburgh, EH1 IHX, Scotland
}

\begin{abstract}
We examined 47 Hafnia alvei strains by performing a numerical analysis of 101 features. The similarity among all of the strains was very high, and these strains formed a single phenon with a simple matching coefficient of more than 0.875 when average-linkage cluster analysis was used. The $H$. alvei strains were distinct from several reference enteric bacteria, including representative Enterobacter strains. The guanosine-plus-cytosine contents of the deoxyribonucleic acids from nine strains were 43.6 to $47.9 \mathrm{~mol} \%$ (mean \pm standard deviation, $45.3 \pm 1.3$ mol\%).
\end{abstract}

The species Hafnia alvei Møller 1954 (16), which was proposed for enterobacteria that demonstrate very strong lysine and ornithine decarboxylase activities and late or absent fermentation of lactose, has received little detailed study and can be a source of confusion to both clinicians and taxonomists (2). An exhaustive biochemical and serological study of 294 strains, which were isolated primarily from patients suffering from acute diarrhoea, indicated that there was sufficient affinity with Enterobacter species for Sakazaki (22) to recommend inclusion of these strains in the species Enterobacter hafniae. For a brief period the organism was reduced to subspecific rank, as Enterobacter aerogenes subsp. hafniae (9), but later it was reinstated as Enterobacter alvei (10) and subsequently was named Hafnia alvei (23), which is the name that appears on the Approved Lists of Bacterial Names (25). Several numerical taxonomic studies of enteric bacteria have included representative strains of $H$. alvei, which almost invariably have been recovered within single well-defined clusters of generic rank $(1,6,12$, $13,24)$. However, few strains have been studied, and in one taxonomic survey, the $H$. alvei strains were separated into two taxa, although the subdivision was not considered to be particularly significant (11). A second indication that $H$. alvei may be heterogeneous originated from deoxyribonucleic acid (DNA) studies in which the guanine-plus-cytosine $(\mathrm{G}+\mathrm{C})$ contents of $H$. alvei DNAs were reported as 52 to $57 \mathrm{~mol} \%$ (24) and 47 to $49 \mathrm{~mol} \%(12,21,28)$. These data suggest either that a discrepancy between laboratories occurred or that there are two distinct taxa. Moreover, preliminary studies have suggested that there may be several DNA homology groups within strains currently classified as $\boldsymbol{H}$. alvei (4).

Numerical techniques have helped clarify the intra- and intergeneric relationships among vari- ous enteric bacteria (14). In the present study, $H$. alvei isolates from various geographical locations and habitats were compared by using numerical taxonomic techniques, and the DNA base compositions of nine strains were determined.

\section{MATERIALS AND METHODS}

Bacterial strains and growth media. The 63 test strains examined included $47 \mathrm{H}$. alvei strains and 16 strains representing 13 other species. The following $H$. alvei strains were used: strains NCTC 6578, NCTC $8105^{\mathrm{T}}$ (type strain), NCTC 8106 , NCTC 8110 , NCTC 8112, NCTC 8585, and NCTC 9540; strains 44 to 53 of R. Sakazaki, National Institute of Health of Japan, Shingawa-Ku, Tokyo, Japan; strains 54, 60, 68, 70, 71, 72, 96, 109, 116, 161, and 120 of F. Gavini, Institut Pasteur de Lille, 59650 Villeneuve d'Asq, France; strains $\mathrm{Cl} / 88 / 75, \mathrm{Cl} / 153 / 75, \mathrm{Cl} / 176 / 75, \mathrm{Cl} / 218 / 75$, $\mathrm{Cl} / 1173 / 76, \mathrm{Cl} / 193 / 76, \mathrm{Cl} / 263 / 76, \mathrm{Cl} / 23 / 77, \mathrm{Cl} / 90 / 77$, and $\mathrm{Cl} / 206 / 77$ of $\mathrm{B}$. Holmes, Central Public Health Laboratory, London, England; and strains E14425, E14299, E14302, E13877, E15883, E15891, and E16208 of R. Gross, Central Public Health Laboratory, London. The strains of other species used were Citrobacter freundii strain NCIB 3735, Edwardsiella tarda strain NCTC $10396^{\mathrm{T}}$, Enterobacter aerogenes strain NCTC $10006^{\mathrm{T}}$, Enterobacter cloacae strain NCTC $10005^{\mathrm{T}}$, Escherichia coli strain K-12, "Klebsiella aerogenes" strain D11, Klebsiella ozaenae strain NCTC $5050^{\mathrm{T}}$, Klebsiella pneumoniae strain NCIB 9261, Obesumbacterium proteus strains $\mathrm{NCIB} 8771^{\mathrm{T}}, 530$, and 540, Proteus mirabilis strain D13, Salmonella typhimurium strain 651, Serratia marcescens strain NCIB 2847, and Yersinia enterocolitica strain NCTC 10450. The test strains were maintained on nutrient agar (Oxoid Ltd., London, England) slopes at $4^{\circ} \mathrm{C}$. A basal medium which supported the growth of all test organisms except the $O$. proteus strains was based on Koser citrate medium (7) and contained $1.0 \mathrm{~g}$ of $\left(\mathrm{NH}_{4}\right)_{2} \mathrm{HPO}_{4}, \quad 1.0 \mathrm{~g}$ of $\mathrm{K}_{2} \mathrm{HPO}_{4}, 0.2 \mathrm{~g}$ of $\mathrm{MgSO}_{4} \cdot 7 \mathrm{H}_{2} \mathrm{O}, 5.0 \mathrm{~g}$ of $\mathrm{NaCl}, 40 \mathrm{mg}$ of L-glutamic acid, $1 \mathrm{mg}$ of nicotinic acid, and 1 liter of distilled water; the $\mathrm{pH}$ was 7.2 . Granulated agar (1.5\%; Oxoid) was added for solid medium. For $O$. proteus strains 0.3 
TABLE 1. Characteristics of $H$. alvei ${ }^{a}$

\begin{tabular}{|c|c|c|c|}
\hline Character & $\begin{array}{c}\% \text { Of strains } \\
\text { showing positive } \\
\text { reaction }(n=47)\end{array}$ & Character & $\begin{array}{l}\% \text { Of strains } \\
\text { showing positive } \\
\text { reaction }(n=47)\end{array}$ \\
\hline Degradation tests & \multicolumn{3}{|c|}{ Growth on sole carbon sources } \\
\hline Esculin & 4 & Acetate & 42 \\
\hline Casein & 2 & Glutamate & 62 \\
\hline DNA & 2 & Histidine & 98 \\
\hline Gelatin & 8.5 & Lysine & 20 \\
\hline Starch & 4 & Malate & 98 \\
\hline Tributyrin & 60 & Malonate & 55 \\
\hline Tyrosine & 2 & Phenylalanine & 8 \\
\hline Tween 20 & 13 & Succinate & 98 \\
\hline Growth tolerance & & Tryptophan & 2 \\
\hline Brilliant green bile agar & 25 & Valine & 2 \\
\hline $\mathrm{NaCl}(7.5 \%)$ & 6 & Biochemical tests & \\
\hline Carbohydrate utilization & & Arginine dihydrolase & 2 \\
\hline D-Arabinose & 4 & Gluconate oxidation & 83 \\
\hline Arbutin & 13 & Methyl red & 21 \\
\hline Cellobiose & 6 & Urease & 4 \\
\hline Lactose & 7 & Motility in semisolid agar & 87 \\
\hline Mannose & 98 & Voges-Proskauer & 87 \\
\hline$\alpha$-Methylglucoside & 2 & Resistance to antibiotics & \\
\hline Raffinose & 4 & Cephaloridine & 70 \\
\hline Rhamnose & 98 & Chloramphenicol & 2 \\
\hline Salicin & 10 & Cloxacillin & 89 \\
\hline Sorbitol & 2 & Erythromycin & 83 \\
\hline Xylose & 98 & Novobiocin & 89 \\
\hline
\end{tabular}

${ }^{a}$ All $H$. alvei strains produced white to yellow, nonmucoid colonies, grew on MacConkey, deoxycholatecitrate, and violet red bile agars, grew in 2 and $5 \% \mathrm{NaCl}$, grew at $\mathrm{pH} 4.9$ and 8.25 , and grew at $4,15,37$, and $44^{\circ} \mathrm{C}$. They utilized L-arabinose, fructose, galactose, glucose, glycerol, maltose, mannitol, ribose, and trehalose but did not utilize adonitol, dulcitol, erythritol, inositol, inulin, melibiose, or sucrose. They formed gas from glucose. Asparagine, lactate, proline, pyruvate, and serine but not arginine, benzoate, butyrate, cysteine, glycine, leucine, muconate, oxalate, proline, propionate, or D-tartrate served as a sole carbon source. Pullulan, ribonucleic acid, Tween 80, and xanthine were not degraded. The strains did not produce $\mathrm{H}_{2} \mathrm{~S}$ or indole in SIM medium and were susceptible to carbenicillin, furazolidone, and neomycin. All strains were positive for lysine and ornithine decarboxylases.

$\mathrm{g}$ of peptone (Oxoid) and $0.1 \mathrm{~g}$ of yeast extract (Oxoid) were added to each 1 liter of basal medium.

Collection of data. Each strain was examined for 101 unit characters (Table 1). Media were inoculated from 24-h (or 48-h in the case of $O$. proteus) nutrient agar plates by suspending a small portion of culture in physiological saline to provide a slightly turbid inoculum. All tests were incubated at $30^{\circ} \mathrm{C}$ unless otherwise stated. Ten strains were duplicated and were included in the study to obtain an estimate of test error.

Colonial morphology. Cultures were grown on nutrient agar for 3 days. Motility was detected in stab cultures of SIM (Difco Laboratories, Detroit, Mich.) medium incubated for 3 days.

Biochemical tests. Arginine dihydrolase and lysine and ornithine decarboxylases were detected by the method of Møller (17). For the gluconate oxidation and malonate utilization tests, method 1 of Cowan (7) was used. Indole production in SIM medium was detected with Kovac reagent (7), and $\mathrm{H}_{2} \mathrm{~S}$ production was detected in the same medium incubated for 5 days. The methods of Cowan (7) were used for the methyl red and Voges-Proskauer reactions, and the inclusion of a Durham tube revealed gas production. Urease activity (5) was read after incubation for 2 days.
Degradation tests. The following compounds were incorporated into nutrient agar: $2.5 \%(\mathrm{wt} / \mathrm{vol})$ skim milk; $0.2 \%$ (wt/vol) calf thymus DNA (Sigma Chemical Co., St. Louis, Mo.); $0.4 \%$ (wt/vol) gelatin; $0.5 \%$ (wt/vol) pullulan (19); $0.2 \%(\mathrm{wt} / \mathrm{vol})$ ribonucleic acid (from Torula yeast; Sigma); $0.5 \%$ (wt/vol) starch; $0.5 \%$ (wt/vol) tyrosine; $1.0 \%$ (wt/vol) Tween $20 ; 1.0 \%$ (wt/vol) Tween 80; and $0.4 \%(\mathrm{wt} / \mathrm{vol})$ xanthine. The cultures were incubated for 7 days. Degradation was detected by flooding nucleic acid plates with $1 \mathrm{M} \mathrm{HCl}$, gelatin plates with acid mercuric chloride, pullulan plates with ethanol, and starch plates with an iodine solution $\left(0.3 \% \mathrm{KI} ; 0.03 \% \mathrm{I}_{2}\right)$. Hydrolysis of Tween 20 or Tween 80 was indicated by an opaque halo; hydrolysis of tyrosine, xanthine, or casein was indicated by clearing. Tributyrin hydrolysis was detected in a commercial medium (Oxoid).

Carbohydrate and organic acid utilization. Carbohydrates $(0.5 \%, w t / v o l$; Table 1$)$ and organic acids $(0.2 \%$, $\mathrm{wt} / \mathrm{vol}$; Table 1) were incorporated into basal medium, and plates were inoculated. Growth compared with a control plate after incubation for 5 days indicated utilization.

Tolerance to $\mathrm{pH}$, temperature, and chemical inhibitors. Growth on nutrient agar in incubators at 4,14 , 
and $37^{\circ} \mathrm{C}$ was examined after incubation for 20,3 , and 3 days, respectively. Growth at $44^{\circ} \mathrm{C}$ was determined in nutrient broth in a water bath after 2 days of incubation. Sodium chloride was added to concentrations of 2,5 , and $7.5 \%(\mathrm{wt} / \mathrm{vol})$ to nutrient agar, and the cultures were incubated for 5 days. Nutrient agar was adjusted to $\mathrm{pH} 5.0$ with $\mathrm{HCl}$ and to $\mathrm{pH} 8.25$ with $\mathrm{NaOH}$ and autoclaved. The $\mathrm{pH}$ was checked before plates were inoculated and incubated for 5 days. Growth responses on deoxycholate citrate agar (Oxoid), MacConkey agar (Oxoid), brilliant green bile agar (BBL Microbiology Systems, Cockeysville, Md.), and violet red bile agar (BBL) were examined after 3 days.

Antibiotic susceptibility. Lawns were prepared by spreading $0.1 \mathrm{ml}$ of a slightly turbid suspension of bacteria over a nutrient agar plate, and antibiotic disks (Diamid Diagnostics, Bootle, Merseyside, United Kingdom) were placed on the surface. The following antibiotic disks were tested: carbenicillin, $10 \mu \mathrm{g}$; chloramphenicol, $10 \mu \mathrm{g}$; cephaloridine, $25 \mu \mathrm{g}$; cloxacillin, $5 \mu \mathrm{g}$; erythromycin, $10 \mu \mathrm{g}$; furazolidone, $50 \mu \mathrm{g}$; neomycin, $30 \mu \mathrm{g}$; and novobiocin, $5 \mu \mathrm{g}$. Growth around the periphery of a disk after incubation for 2 days was recorded as positive (resistance).

Analysis of data. Nearly all of the characters existed in one of two mutually exclusive states and were scored plus or minus. Qualitative multistate characters, such as colony morphology, were scored plus for the character state shown and minus for the alternative character states. Resistance to antimicrobial agents was scored as plus. The table which we constructed contained data for 63 bacteria and 101 characters.

Data were analyzed by the Clustan $1 \mathrm{C}$ program (30), using both the simple matching coefficient (27) and the Dice index (8), which gives weight to positive matches and excludes negative matches. Clustering was achieved by unweighted average-linkage analysis (27).

Preparation of DNA. Strains were grown in Oxoid nutrient broth (1 liter of broth in 2-liter flasks) in an orbital incubator for $20 \mathrm{~h}$. The cells were harvested, washed in $0.1 \mathrm{M}$ ethylenediaminetetraacetate $-0.5 \mathrm{M}$ $\mathrm{NaCl}(\mathrm{pH} \mathrm{8.0})$, and then suspended in $40 \mathrm{ml}$ of $0.1 \mathrm{M}$ ethylenediaminetetraacetate-0.5 M NaCl (pH 8.0). Sodium dodecyl sulfate was added to a concentration of $2 \%(\mathrm{wt} / \mathrm{vol})$, and the preparation was heated at $60^{\circ} \mathrm{C}$ for $10 \mathrm{~min}$. Then the method of Mordarski et al. (18) was followed, and final preparations were dialyzed extensively against $0.1 \times \mathrm{SSC}(1 \times \mathrm{SSC}$ is $0.15 \mathrm{M} \mathrm{NaCl}$ plus $0.015 \mathrm{M}$ trisodium citrate, $\mathrm{pH} 7.0$ ). The purity of the DNA was assessed by determining the ratio of absorbance at $260 \mathrm{~nm}\left(A_{260}\right)$ to $A_{280}$ and the ratio of $\mathbf{A}_{255}$ to $\mathbf{A}_{230}$. All preparations had $\mathbf{A}_{260} / \mathbf{A}_{280}$ ratios in the range from 1.86 to 2.03 and $A_{255} / A_{230}$ ratios of $>2.1$.

DNA base composition. DNA in $0.1 \times \mathrm{SSC}$ was diluted to a concentration of approximately $20 \mu \mathrm{g} / \mathrm{ml}$, and the $\mathrm{A}_{260}$ at $25^{\circ} \mathrm{C}$ was recorded with a Pye model SP8100 spectrophotometer. The temperature of the solution was raised to $65^{\circ} \mathrm{C}$, and the preparation was equilibrated for $10 \mathrm{~min}$. Then the temperature was raised in $2^{\circ} \mathrm{C}$ intervals, allowing $5 \mathrm{~min}$ for equilibration at each stage. The temperature within the cuvette was recorded up to $80^{\circ} \mathrm{C}$ by using an electronic thermometer. The midpoint of the hyperchromic shift $\left(T_{m}\right)$ was calculated and was related to the $\mathrm{G}+\mathrm{C}$ content by the following equation (20): $\mathrm{G}+\mathrm{C}$ content of test DNA =
$\mathrm{G}+\mathrm{C}$ content of reference DNA $+2.08\left(T_{m}\right.$ of test DNA $-T_{m}$ of reference DNA). The $\mathrm{G}+\mathrm{C}$ content of the reference DNA (from Escherichia coli B) was taken as $50.9 \mathrm{~mol} \%$.

\section{RESULTS}

Numerical analysis. Tests for 10 strains were duplicated and were included in the study to provide an estimate of test error (26). The probability of any test being incorrect was $5.8 \%$, well within the standards generally accepted for such a study.

By using the simple matching coefficient and the unweighted average-linkage clustering algorithm, the $47 \mathrm{H}$. alvei strains studied were grouped in a single taxon at a similarity of $87.5 \%$ (Fig. 1). The type culture was located near the center of this phenon. The reference strains joined the $H$. alvei cluster at a similarity value of $84 \%$. The order of these strains was largely in accord with the current classification of enteric bacteria, and the relatively low affinity of these strains with $H$. alvei substantiates that $H$. alvei is a distinct taxon. Three $O$. proteus strains included in the study clustered together but were quite distant from $H$. alvei.

The Dice coefficient gives positive characters in common twice the weight of unmatched pairs and is monotonic with the Jaccard coefficient. The Dice coefficient was used in this study because a previous taxometric analysis revealed two possible clusters of $H$. alvei strains when this coefficient was used (11). However, in our study the $47 \mathrm{H}$. alvei strains were recovered in a single phenon at a similarity of $84 \%$. The order of strains was similar to that obtained when the simple matching coefficient was used, and there was no evidence of subdivision in the cluster. The reference strains joined $H$. alve $i$ at a similarity level of $78 \%$ and clustered in an order similar to that shown in Fig. 1.

The properties of the strains in the $H$. alvei phenon are shown in Table 1. With few exceptions, these strains failed to degrade polymeric materials, were tolerant to various bile-salt-containing media, and had a wide temperature range for growth. They fermented glucose to acid and gas and metabolized a variety of carbohydrates, including L-arabinose, glycerol, mannose, maltose, mannitol, rhamnose, ribose, trehalose, and xylose. Most strains were Voges-Proskauer positive and negative for the indole and urease tests. All $H$. alvei strains decarboxylated lysine and ornithine. The type strain (NCTC 8105) was atypical in being urease and arginine dihydrolase positive.

DNA base composition. The $T_{m}$ values of DNA preparations from nine $H$. alve $i$ strains ranged from 72.0 to $74.05^{\circ} \mathrm{C}$ (mean \pm standard deviation, $72.8 \pm 0.66^{\circ} \mathrm{C}$ ). All determinations were 


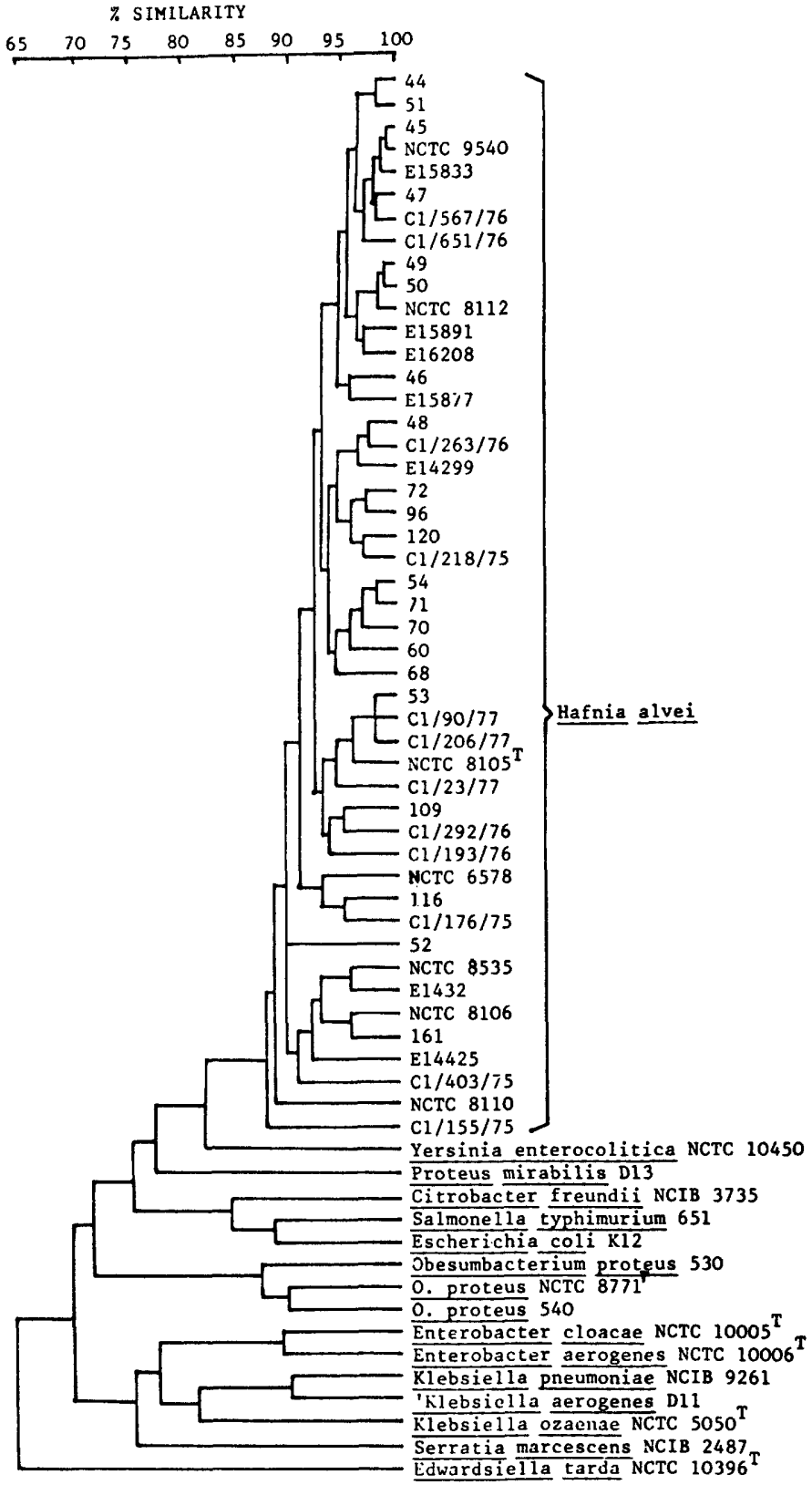

FIG. 1. Dendrogram showing the relationships among strains based on the simple matching coefficient and unweighted average-linkage clustering.

performed at least twice and showed a mean standard deviation of $\pm 0.17^{\circ} \mathrm{C}$. Under the same experimental conditions, Escherichia coli B DNA had a $T_{m}$ of $75.6^{\circ} \mathrm{C}$. When we used the equation developed by Owen and Hill (20) relating $T_{m}$ to $\mathrm{G}+\mathrm{C}$ content, we found that our results represented a mean $\mathrm{G}+\mathrm{C}$ content for the nine $H$. alvei strains of $45.3 \pm 1.3 \mathrm{~mol} \%$. The individual $\mathrm{G}+\mathrm{C}$ determinations were as follows: strain $45,43.6 \mathrm{~mol} \%$; strain $60,44.2 \mathrm{~mol} \%$; strain NCTC 8106, 44.3 mol\%; strain 70, 44.9 mol\%; strain 46, 45.1 mol\%; strain E13877, 45.2 mol\%; strain 53, 46.2 mol\%; strain NCTC 6578, $46.8 \mathrm{~mol} \%$; and strain NCTC $8110,47.8 \mathrm{~mol} \%$.

\section{DISCUSSION}

The $H$. alvei strains used in this study represent four sets of isolates that originated from Great Britain, France, Japan, and the United 
States. Although individually strains have been subjected to previous taxometric analyses $(1,6$, $11,13,24)$, this is the first time that such geographically distinct strains of this species have been compared. Therefore, it is interesting that all 47 strains formed a homogeneous phenon clearly separated from the reference strains. A previous numerical analysis indicated that $H$. alvei may be composed of two aggregates of strains, although there were no phenotypic attributes which could be used to distinguish these taxa (11). Representatives of both of these subgroups were included in this study, but, despite various computations, the subgroups were not apparent.

The characteristics of $H$. alvei listed in Table 1 are in close agreement with similar data from other studies $(1,6,13,24)$, but it is difficult to highlight characteristics that distinguish $H$. alvei from other enterobacteria. Decarboxylation of lysine and ornithine, a negative (with the notable exception of the type strain) arginine dihydrolase reaction with fermentation of $\mathrm{L}$-arabinose, rhamnose, ribose, trehalose, and D-xylose, and the inability to ferment adonitol, inositol, and melibiose are characteristic. Since this work was completed, Brenner (4) has shown that there are two major DNA hybridization groups in $H$. alvei. Although no single biochemical test distinguished these taxa, a series of reactions could be used to separate them. In particular, group 2 strains were motile, did not ferment arbutin or salicin, and were urease negative. On the other hand, group 1 strains showed variable reactions to arbutin, salcin, and urea and were generally nonmotile after $24 \mathrm{~h}$ of growth. Therefore, it seems likely that the strains which we studied represent group 2 since they were largely urease, arbutin, and salicin negative and were motile. Brenner has distinguished a third hybridization group of atypical $H$. alvei strains (4). Thus, although our results show a relatively homogeneous taxon, this may reflect a phenotypically conserved but genetically diverse group of organisms. Alternatively, despite the geographically dispersed origins of the strains which we studied, representatives of the DNA homology groups were not included.

A bacterium commonly encountered in beerbrewing yeasts has been transferred to Hafnia as Hafnia protea (21), although on the Approved Lists of Bacterial Names (25) this organism retains its previous designation, Obesumbacterium proteus. Three strains representing the two biotypes (21) of this organism were included in the present study. These strains did not cluster near $H$. alvei, but this might be expected since although $O$. proteus biotype 1 (strains 540 and NCIB $8771^{\mathrm{T}}$ ) share considerable DNA homology with $H$. alvei, they are phenetically distinct
(4). Moreover $O$. proteus biotype 2 is phenetically and genetically distinct from $H$. alvei $(4,29)$.

The determinations of the $T_{m}$ values of the DNAs from nine $H$. alvei strains indicate that $H$. alvei DNA has a mean $\mathrm{G}+\mathrm{C}$ content of $45.3 \pm$ $1.3 \mathrm{~mol} \%$, although taking the $\mathrm{G}+\mathrm{C}$ content of Escherichia coli B DNA as $52 \mathrm{~mol} \%$, would raise this value by $1 \mathrm{~mol} \%$. This value is slightly lower than the previously published values for $H$. alvei DNA (47 to $48 \mathrm{~mol} \%)(12,21,28)$ but lies within the generally accepted $5 \mathrm{~mol} \%$ variation for a genus (3) and readily distinguishes Hafnia from the majority of other enteric bacteria.

\section{LITERATURE CITED}

1. Bascomb, S., S. P. Lapage, W. R. Willcox, and M. A. Curtis. 1971. Numerical classification of the tribe Klebsielleae. J. Gen. Microbiol. 66:279-295.

2. Berger, S. A., S. C. Edberg, and R. S. Klein. 1977. Enterobacter hafniae infection: report of two cases and review of the literature. Am. J. Med. Sci. 273:101-104.

3. Bradley, S. G., and M. Mordarski. 1976. Association of deoxyribonucleotides of deoxyribonucleic acids of nocardioform bacteria, p. 310-336. In M. Goodfellow, G. H. Brownell, and J. A. Serrano (ed.), The biology of the nocardiae. Academic Press, Inc., London.

4. Brenner, D. J. 1981. Introduction to the family Enterobacteriaceae, p. 1105-1127. In M. P. Starr, H. Stolp, H. G. Truper, A. Balows, and H. G. Schlegel (ed.), The prokaryotes, a handbook on habitats, isolation and identification of bacteria. Springer-Verlag, Berlin.

5. Christensen, W. B. 1946 . Urea decomposition as a means of differentiating Proteus and paracolon cultures from each other and from Salmonella and Shigella. J. Bacteriol. 52:461-468.

6. Colwell, R. R., R. Johnson, L. Wan, T. E. Lovelace, and D. J. Brenner. 1974. Numerical taxonomy and deoxyribonucleic acid reassociation in the taxonomy of some gramnegative fermentative bacteria. Int. J. Syst. Bacteriol. 24:422-433.

7. Cowan, S. T. 1974. Cowan and Steel's manual for the identification of medical bacteria, 2nd ed. Cambridge University Press, Cambridge.

8. Dice, L. R. 1945. Measures of the amount of ecologic association between species. Ecology 26:297-302.

9. Ewing, W. H. 1963. An outline of nomenclature for the family Enterobacteriaceae. Int. Bull. Bacteriol. Nomencl. Taxon. 13:95-99.

10. Ewing, W. H., and M. A. Fife. 1968. Enterobacter hafniae ("the Hafnia group"'). Int. J. Syst. Bacteriol. 18:263-271.

11. Gavini, F., C. Ferragut, B. Lefebvre, and H. Leclerc. 1976. Etude taxonomique d'enterobacteries appartenant ou apparentées au genre Enterobacter. Ann. Microbiol. (Paris) 127B:317-335.

12. Izard, D., C. Ferragut, F. Gavini, and H. Leclerc. 1978. Variations of the moles percent guanine plus cytosine within a group of Enterobacteriaceae belonging or related to the genus Enterobacter. Int. J. Syst. Bacteriol. 24:449452.

13. Johnson, R., R. R. Colwell, R. Sakazaki, and K. Tamura. 1975. Numerical taxonomic study of the Enterobacteriaceae. Int. J. Syst. Bacteriol. 25:12-37.

14. Jones, D., and M. J. Sackin. 1980 . Numerical methods in the classification and identification of bacteria with especial reference to the Enterobacteriaceae, p. 73-106. In M. Goodfellow and R. G. Board (ed.), Microbiological classification and identification. Academic Press, Inc., London.

15. Marmur, J., and P. Doty. 1962. Determination of the base composition of deoxyribonucleic acid from its thermal 
denaturation temperature. J. Mol. Biol. 5:107-118.

16. Møller, V. 1954. Distribution of amino acid decarboxylases in Enterobacteriaceae. Acta Pathol. Microbiol. Scand. 35:259-277.

17. Møller, V. 1955. Simplified test for some amino acid decarboxylases and for the arginine dihydrolase system. Acta Pathol. Microbiol. Scand. 36:158-172.

18. Mordarski, M., K. Syzba, G. Pulverer, and M. Goodfellow. 1976. Deoxyribonucleic acid reassociation in the classification of the 'rhodochrous' complex and allied taxa. J. Gen. Microbiol. 94:235-245.

19. Morgan, F. J., K. R. Adams, and F. G. Priest. 1979. A cultural method for the detection of pullulan degrading enzymes and its application to the genus Bacillus. J. Appl. Bacteriol. 46:291-294.

20. Owen, R. J., and L. R. Hill. 1979. The estimation of base compositions, base pairing and genome sizes of bacterial deoxyribonucleic acids, p. 277-296. In F. A. Skinner and D. W. Lovelock (ed.), Identification methods for microbiologists, 2nd ed. Academic Press, Inc., London.

21. Priest, F. G., H. J. Somerville, J. A. Cole, and J. S. Hough. 1973. The taxonomic position of Obesumbacterium proteus, a common brewery contaminant. J. Gen. Microbiol. 75:295-307.

22. Sakazaki, R. 1961. Studies on the Hafnia group of Enterobacteriaceae. Jpn. J. Med. Sci. Biol. 14:223-241.

23. Sakazaki, R. 1974. Genus VIII, Hafnia, p. 325-326. In
R. E. Buchanan and N. E. Gibbons (ed.), Bergey's manual of determinative bacteriology, 8th ed. The Williams \& Wilkins Co., Baltimore.

24. Sakazaki, R., K. Tamura, R. Johnson, and R. R. Colwell. 1976. Taxonomy of some recently described species in the family Enterobacteriaceae. Int. J. Syst. Bacteriol. 26:158179.

25. Skerman, V. B. D., V. McGowan, and P. H. A. Sneath (ed.). 1980. Approved lists of bacterial names. Int. J. Syst. Bacteriol. 30:225-420.

26. Sneath, P. H. A., and R. Johnson. 1972. The influence on numerical taxonomic similarities of errors in microbiological tests. J. Gen. Microbiol. 72:377-392.

27. Sneath, P. H. A., and R. R. Sokal. 1973. Numerical taxonomy: the principles and practice of numerical classification. W. H. Freeman, San Francisco.

28. Starr, M. P., and M. Mandel. 1969. DNA base composition and taxonomy of phytopathogenic and other enterobacteria. J. Gen. Microbiol. 19:551-565.

29. Van Vuuren, H. J. J., K. Kersters, and J. De Ley. 1981. The identification of Enterobacteriaceae from breweries: combined use and comparison of API $20 \mathrm{E}$ system, gel electrophoresis of proteins and gas chromatography of volatile metabolites. J. Appl. Bacteriol. 51:51-65.

30. Wishart, D. 1978. Clustan user manual, 3rd ed. Edinburgh Program Library Unit, Edinburgh University, Edinburgh, Scotland. 